\title{
Determinants Affecting Thai Merchant Marine Students' Decision in Selecting a Maritime Institute in Thailand: Nautical Science Program
}

\author{
+ Sarawut Luksanato \\ + Faculty of Logistics, Burapha University, 169 Saen Sook Chonburi, Kingdom of Thailand
}

\begin{abstract}
The objective of the research was to study the determinants affecting the decision to study nautical science program within a Thai maritime institute in preparation for working post-graduation as a ship officer on a merchant ship. The samples are classified by institute, academic year, cumulative score level, domicile, and parent's monthly income. The total sample of study was 386 Thai merchant marine students. The data collection method was a one to five rating scale questionnaire. The statistical methods applied in analyzing the data were percentage, mean, standard deviation, t-test, one way analysis of variance and a Sheffe's test. The study shows seven factors that influenced the decision in descending order; expectations, tuition and scholarships, selection system, quality of the institute, backgrounc and private capability, generality of the institute and external influences on the decision. The decision to select an institute was classifiea by institute and revealed that different institutes had distinct determinants that led to the decision. The students were from The Merchant Marine Training Center and from The International Maritime College, Kasetsart University were differences. There were no dissimilarity between academic year, cumulative score level, domicile, and parent's monthly income.
\end{abstract}

Key words : Merchant Marine Student, Maritime Institutes, Nautical Science Program

\section{INTRODUCTION}

Although there are no dedicated maritime universities in Thailand as other countries have Thailand has three public institutes that are training mariner officers for both domestic and international shipping companies, Currently there are three institutions, The Merchant Marine Training Center (MMTC) , The Faculty of Logistics (LF) of Burapha University and The International Maritime College (IMC) of Kasetsart University. In Thailand, graduating high school students who would like to pursue a career as a mariner officer to work on merchant ship, will choose to enroll in one of the above three institutes. Each institute is outstanding and unique in different ways but each have similar academic standards in order to produce high-potential students creating qualified mariner officers and build up their reputations as a first rate institutes.

The goal of university education is to focus on the creating quality graduates with the knowledge and decision making processes that meet the needs of society and modernizing trends in the world today Thai Instructor
Senate (2003). Maritime institutes are public institutions at the university level and responsible for creating mariner officers. Therefore, they need to consistently develop their organization and produce qualified personal in accordance with the Standards of Training Certification and Watchkeeping (STCW) 2010. In Thailand, 93.44\% of graduating high school students continues their education at university level. Thai Ministry of Education (2010). A portion of these students decide to study in a maritime institute within a nautical science program from one of the three institutes available in the country. Thus, maritime institutes in Thailand are competing to attract high-potential students to study at their institution. The determination of the factors affecting the decision which maritime institute a mariner officer chooses after graduation is an important knowledge base to understand in order develop future strategies to improve maritime institutes in Thailand; this in turn will have an impact on creating improved mariner officers and the nations maritime industry in the future.

\footnotetext{
† Corresponding author, sarawut@huu.ac.th
} 


\section{LITERATURE REVIEW}

Saithanu and Mekparyup (2011) studied an application which employs a practical method for finding the influential variables or factors of decision in continuing study for Master's degree of the fourth year students (224 persons), Faculty of Science, Burapha University, by the use of factor analysis. The model predicted the decision in continuing study for a master's degree and then was later modeled by discriminant analysis. The result of this research showed eight influential variables: GPA, number of persons in family who finished their Master's degree, status of family, progress in working, the cost of continuing study, social acceptance, knowledge and skill and competence of the faculty. The model was built through use of a cross validation data set, confusion matrix provides the correction percentage is up to $71.90 \%$.

Kulprapa (2009) studied the factors affecting the selection of a university by undergraduate students at Sripathum University. The results showed that the university itself was the most important factor. Most students belong to a continuous student loan program. Motivation varied on gender, year of study, faculty, GPA and loan status of personal factors at significance level 0.05 and also varies on father's income, mother's income and family expense per month of family background factors at significance level 0.05. Personal factors are related to family background factors. According to the study, the university should emphasize its quality such as educational services, environment and technologies, which are considered the major factors that influence on the motivation of undergraduate students to make their choices of education.

Boonchaiyah (2008) studied the motivation factor for further master degree in recreation at Srinakharinwirot University according to the sex, age, education in bachelor's degree and experience. The results of the research found that the motivation factor for furthering master degree in recreation at Srinakharinwirot University in overall aspect was high level and each aspect, it was found self-development, related person compliance were highest and institution, social, occupation were high level. The students with different genders had a motivating factor in overall aspect was high level and each aspect, it was found self- development, related person compliance were highest and institution, social, occupation were high level. The students with different ages had varying motivating factors in overall aspect was high level and each aspect, it was found self-development, related person compliance were highest and institution, social, occupation were high level. The students with different bachelor degrees had motivating factors in overall aspect was high and each aspect, it was found self-development, related person compliance were highest and institution, social, occupation were high level. The students with different working experiences had motivating factors in overall aspect was high and each aspect, it was found self-development, related person compliance were highest and institution, social, occupation were high level.

Haruehansawasin and Kiattikomol (2008) studied factors affecting high school graduates decisions to further study in high vocational certificate level in business computer major, case of private vocational schools in Bangkok. Data was analyzed by using frequency, percentage, mean, standard deviation, and factors analysis. The results revealed that factors were: 1) Future expectation 2) School's regulation 3) Personal attitude to Business Computer major 4) Teaching's media 5) School's services 6) School's reputation 7) Academic strength and facilities 8) Public relations media 9) Scholarship and 10) Personal persuasion and direct marketing strategies.

Lunsucheep (2002) studied the motivation to study at Mahidol University International College the results showed that the subjects have a high motivation to study at MUIC due to four factors namely; personal factors, social factors, employment factors and institutional factors. After considering each factor, it was found that the personal factor of the motivation to study at MUIC consisted of course being taught in English, while the social factor of the motivation to study at MUIC is that the subject gained experience in relation to the institute and international companies. Apart from this, employment factors provided motivation to study at MUIC in that the subjects need employment with high remuneration and institutional factors towards the motivation to study at MUIC is that the instructors have sound capabilities.

Glasser (1996) summarized the ten principles of Choice Theory. Firstly, only persons whose behavior we can control is our own. Secondly, all we can give another person is information. Thirdly, all long lasting psychological 
problems are relationship problems. Fourthly, the problem relationship is always part of our present life. Fifth, what happened in the past has everything to do with what we are today, but we can only satisfy our basic needs right now and plan to continue satisfying them in the future. Sixth, we can only satisfy our needs by satisfying the pictures in our quality world. Seventh, all we do is behave. Eighth, all behavior is total behavior and is made up of four components: acting, thinking, feeling and physiology. Ninetieth, all total behavior is chosen, but we only have direct control over the acting and thinking components, we can only control our feeling and physiology indirectly through how we choose to act and think. Lastly, all total behavior is designated by verbs and named by the part that is the most recognizable.

\section{MATERIAL AND METHODS}

\section{1 Population and sample}

The samples of the research questionnaire were Thai merchant marine students from three maritime institutes using a simple random sampling. A total 386 samples responded to the questionnaire survey.

\subsection{Collecting research data}

Based on a literature study from related document, textbook and research it created research variables and questionnaire. Likert scale is used to this study to express how much they agree or disagree with a particular statement. The format of a typical 5 levels Likert item is strongly disagree, disagree, neither agree nor disagree, agree and strongly agree. Questionnaire created by attitude components presented 5 levels of Likert rating scale. The 29 research variables in questionnaire were evaluated by index of item objective congruence technique (IOC), afterwards tries out the test to non-actual samples of 30 persons and evaluates discrimination value of questionnaire in each item by applying t-test to select item which has discrimination higher than 1.734. It also evaluates reliability value of questionnaire by $a^{-}$-coefficient evaluation.

\subsection{Statistic applied for data analysis}

It used basic statistical analysis such as mean and standard deviation. And then statistics applied for quality determination included discrimination evaluation by using t-test and reliability analysis by $a$-coefficient evaluation. Difference of mean test of two more samples was applied by One Way Analysis of Variance. When One Way Analysis of Variance gave a significant result or case of the differences were significant statistically. This indicated that at least one group differed from the other groups, therefore the test method of Scheffe was examined.

\section{RESULTS}

\subsection{Basic statistical analysis of samples}

From table 1 institutes content, most marine student samples are from IMC 47.7\%, secondly from MMTC 37.0\% and lastly from LF 15.3\%. Academic year content, most marine student samples are from 1st year level 36.0\%, secondly from 2nd year level 31.1\%, thirdly from 3rd year level $24.6 \%$, fourthly from 4 th year level $7 \%$, fifthly from 5 th year level $0.3 \%$ and lastly no response $1.0 \%$. Cumulative score level content, most marine student samples are 2.51-3.00 grade level 44.3\%, secondly 2.01-2.50 grade level 28.2\%, thirdly 3.01-3.50 grade level 15.3\%, fourthly not over 2.01 grade level $6.2 \%$ fifth, over 3.50 grade level $4.9 \%$ and lastly no response $1.1 \%$. Domicile content, most marine student samples are from east region $28.2 \%$, Bangkok and circumference $18.1 \%$, central region and west region 15.3\%, north region $15.3 \%$, northeast region $12.4 \%$, southern region $9.6 \%$ and no response $1.1 \%$. Parent's monthly income content, most marine student samples are 10,001-20,000 baht 30.3\%, 20,001-30,000 baht $25.4 \%$, over 40,000 baht $17.4 \%, 30,001-40,000$ baht $16.8 \%$ no response $1.3 \%$ 
Table 1 Basic statistic analysis of samples

\begin{tabular}{|c|c|c|c|}
\hline & Research variables & Amount & Percentage \\
\hline \multirow[t]{4}{*}{ Institutes } & MMTC & 143 & 37.0 \\
\hline & $\mathrm{LF}$ & 59 & 15.3 \\
\hline & $\mathrm{IMC}$ & 184 & 47.7 \\
\hline & Total & 386 & 100.0 \\
\hline \multirow{7}{*}{$\begin{array}{l}\text { A c a d e m ic } \\
\text { year }\end{array}$} & First & 139 & 36.0 \\
\hline & Second & 120 & 31.1 \\
\hline & Third & 95 & 24.6 \\
\hline & Fourth & 27 & 7.0 \\
\hline & Fifth & 1 & 0.3 \\
\hline & No response & 4 & 1.0 \\
\hline & Total & 386 & 100.0 \\
\hline \multirow{7}{*}{$\begin{array}{l}\text { Cumulative } \\
\text { score level }\end{array}$} & Not over 2.01 & 24 & 6.2 \\
\hline & $2.01-2.50$ & 109 & 28.2 \\
\hline & $2.51-3.00$ & 171 & 44.3 \\
\hline & $3.01-3.50$ & 59 & 15.3 \\
\hline & Over 3.50 & 19 & 4.9 \\
\hline & No response & 4 & 1.1 \\
\hline & Total & 386 & 100.0 \\
\hline \multirow[t]{8}{*}{ Domicile } & $\begin{array}{l}\text { Bangkok and } \\
\text { circumference }\end{array}$ & 70 & 18.1 \\
\hline & North region & 59 & 15.3 \\
\hline & Northeast region & 48 & 12.4 \\
\hline & East region & 109 & 28.2 \\
\hline & $\begin{array}{l}\text { Central region and } \\
\text { West region }\end{array}$ & 59 & 15.3 \\
\hline & Southern region & 37 & 9.6 \\
\hline & No response & 4 & 1.1 \\
\hline & Total & 386 & 100.0 \\
\hline \multirow{7}{*}{$\begin{array}{l}\text { Parent's } \\
\text { monthly } \\
\text { income } \\
\text { (Baht) }\end{array}$} & Not over 10,000 & 34 & 8.8 \\
\hline & $10,001-20,000$ & 117 & 30.3 \\
\hline & $20,001-30,000$ & 98 & 25.4 \\
\hline & $30,001-40,000$ & 65 & 16.8 \\
\hline & Over 40,000 & 67 & 17.4 \\
\hline & No response & 5 & 1.3 \\
\hline & Total & 386 & 100.0 \\
\hline
\end{tabular}

Table 2 Classified by back ground and private capacity

\begin{tabular}{llcccc}
\hline Item & \multicolumn{1}{c}{ Factor } & $\overline{\mathrm{x}}$ & S.D. & Level & Sequence \\
\hline 1. & English skill & 3.54 & 0.853 & High & 3 \\
2. & Admission score & 3.45 & 0.942 & Medium & 5 \\
3. & Physical ability & 3.61 & 0.850 & High & 1 \\
4. & $\begin{array}{l}\text { Parent's monthly } \\
\text { income }\end{array}$ & 3.61 & 0.902 & High & 1 \\
5. & Parent's career & 3.49 & 1.012 & Medium & 4 \\
\hline & Total & 3.54 & 0.91 & High & \\
\hline
\end{tabular}

\subsection{Factors affecting to select the maritime institutes}

From table 2 overview of factors affecting to select the maritime institutes that classified by back ground and private capacity are high level $(\overline{\mathrm{x}}=3.54)$. The top three of them are physical ability and parent's monthly income $(\overline{\mathrm{x}}=$ 3.61) and English skill $(\overline{\mathrm{x}}=3.54)$ respectively.

From table 3 overview of factors affecting to select the maritime institutes that classified by student expectations are high level $(\overline{\mathrm{x}}=3.94)$. The top three of them are income after graduation $(\overline{\mathrm{x}}=4.09)$, acknowledgement from shipping companies $(\overline{\mathrm{x}}=3.92)$ and pride and love in institutes $(\overline{\mathrm{x}}=$ 3.80) respectively.

Table 3 Classified by student expectations

\begin{tabular}{llcccc}
\hline Item & \multicolumn{1}{c}{ Factor } & $\overline{\mathrm{x}}$ & S.D. & Level & Sequence \\
\hline 1. & $\begin{array}{l}\text { Income after } \\
\text { graduation }\end{array}$ & 4.09 & 0.793 & High & 1 \\
2. & $\begin{array}{l}\text { Pride and love in } \\
\text { institutes }\end{array}$ & 3.80 & 0.867 & High & 3 \\
$\begin{array}{l}\text { Acknowledgement } \\
\text { from shipping } \\
\text { companies }\end{array}$ & 3.92 & 0.813 & High & 2 \\
\hline Total & 3.94 & 0.82 & High & \\
\hline
\end{tabular}

From table 4 overview of factors affecting to select the maritime institutes program that classified by external influences are medium level $(\overline{\mathrm{x}}=3.37)$. The top three of them are senior or alumni of high school $(\overline{\mathrm{x}}=3.52)$, online advertising of marine institutes $(\overline{\mathrm{x}}=3.41)$, idol graduated from this maritime institutes $(\overline{\mathrm{x}}=3.38)$ and also various printing media of maritime institutes $(\overline{\mathrm{x}}=3.38)$ respectively. Least significant is recommendation from friends (3.23).

Table 4 Classified by external influences

\begin{tabular}{|c|c|c|c|c|c|}
\hline Item & Factor & $\overline{\mathrm{x}}$ & S.D. & Level & Sequence \\
\hline 1. & $\begin{array}{l}\text { Senior or alumni of } \\
\text { high school }\end{array}$ & 3.52 & 0.923 & High & 1 \\
\hline 2. & $\begin{array}{l}\text { Advisement in } \\
\text { high school }\end{array}$ & 3.31 & 0.971 & Medium & 5 \\
\hline 3. & $\begin{array}{l}\text { Recommendation } \\
\text { from friends }\end{array}$ & 3.23 & 0.935 & Medium & 6 \\
\hline 4. & $\begin{array}{l}\text { Idol graduated } \\
\text { from this maritime } \\
\text { institutes }\end{array}$ & 3.38 & 0.980 & Medium & 3 \\
\hline 5. & $\begin{array}{l}\text { Online advertising } \\
\text { of marine institutes }\end{array}$ & 3.41 & 0.945 & Medium & 2 \\
\hline 6. & $\begin{array}{l}\text { Various printing } \\
\text { media of maritime } \\
\text { institutes }\end{array}$ & 3.38 & 0.885 & Medium & 3 \\
\hline & Total & 3.37 & 0.94 & Medium & \\
\hline
\end{tabular}


From table 5 overview of factors affecting to select the maritime institutes that classified by admission system are high level $(\overline{\mathrm{x}}=3.68)$. The top three of them are institutes pattern $(\bar{x}=3.78)$, total students for admittance in each year $(\overline{\mathrm{x}}=3.66)$ and subject test $(\overline{\mathrm{x}}=3.65)$ respectively. Least significant item is competition ratio $(\overline{\mathrm{x}}=3.61)$.

Table 5 Classified by admission system

\begin{tabular}{llcccc}
\hline Item & \multicolumn{1}{c}{ Factor } & $\overline{\mathrm{x}}$ & S.D. & Level & Sequence \\
\hline 1. & Institutes pattern & 3.78 & 0.772 & High & 1 \\
2. & Subject test & 3.65 & 0.847 & High & 3 \\
3. & Competition ratios & 3.61 & 0.886 & High & 4 \\
$\begin{array}{l}\text { 4. } \\
\begin{array}{l}\text { Total students for } \\
\text { admittance in each }\end{array} \\
\quad \text { year }\end{array}$ & & & & \\
& Total & 3.66 & 0.882 & High & 2 \\
\hline
\end{tabular}

From table 6 overview of factors affecting to select the maritime institutes that classified by quality of education are high level $(\overline{\mathrm{x}}=3.67)$. The top three of them are institutes' renown $(\overline{\mathrm{x}}=3.85)$, success of students and alumnies $(\overline{\mathrm{x}}=3.61)$ and instructors' renown $(\overline{\mathrm{x}}=3.54)$ respectively.

Table 6 Classified by quality of education

\begin{tabular}{llcccc}
\hline Item & \multicolumn{1}{c}{ Factor } & $\overline{\mathrm{x}}$ & S.D. & Level & Sequence \\
\hline 1. & Institutes' renown & 3.85 & 0.817 & High & 1 \\
2. & Instructors' renown & 3.54 & 0.897 & High & 3 \\
\multirow{2}{*}{ 3. } & $\begin{array}{l}\text { Success of student } \\
\text { and alumnies }\end{array}$ & 3.61 & 0.880 & High & 2 \\
\hline & Total & 3.67 & 0.86 & High & \\
\hline
\end{tabular}

From table 7 overview of factors affecting to select the maritime institutes that classified by generality of institutes are high level $(\overline{\mathrm{x}}=3.53)$. The top three of them are education aid $(\overline{\mathrm{x}}=3.63)$, institutes location $(\overline{\mathrm{x}}=3.59)$ and facilities $(\overline{\mathrm{x}}=3.54)$ respectively. Least significant is space area and modernization $(\overline{\mathrm{x}}=3.40)$.

Table 7 Classified by generality of institutes

\begin{tabular}{llcccc}
\hline Item & \multicolumn{1}{c}{ Factor } & $\overline{\mathrm{x}}$ & S.D. & Level & Sequence \\
\hline 1. & $\begin{array}{l}\text { Space area and } \\
\text { modernization }\end{array}$ & 3.40 & 1.026 & Medium & 5 \\
2. & $\begin{array}{l}\text { Educational aid } \\
\text { 3. }\end{array}$ & 3.63 & 0.926 & High & 1 \\
3. $\begin{array}{l}\text { Sylvan and area } \\
\text { sylvan of }\end{array}$ & 3.49 & 0.982 & Medium & 4 \\
4. Facilities & 3.54 & 1.020 & High & 3 \\
5. & Institutes location & 3.59 & 0.893 & High & 2 \\
\hline & Total & 3.53 & 0.97 & High & \\
\hline
\end{tabular}

From table 8 overview of factors affecting to select the maritime institutes that classified by tuition fee and scholarship are high level $(\overline{\mathrm{x}}=3.77)$. The top three of them are institute tuition fees $(\overline{\mathrm{x}}=3.79)$, institute's budget for both domestic and international training $(\overline{\mathrm{x}}=3.77)$ and scholarship offer $(\overline{\mathrm{x}}=3.74)$ respectively

Table 8 Classified by tuition fee and scholarship

\begin{tabular}{llcccc}
\hline Item & \multicolumn{1}{c}{ Factor } & $\overline{\mathrm{x}}$ & S.D. & Level & Sequence \\
\hline 1. $\begin{array}{l}\text { Institutes tuition } \\
\text { fees }\end{array}$ & 3.79 & 0.871 & High & 1 \\
2. & $\begin{array}{l}\text { Scholarship offer } \\
\text { Institute's budget for } \\
\text { both domestic and } \\
\text { international traing }\end{array}$ & 3.74 & 0.852 & High & 3 \\
\hline Total & 3.77 & 0.944 & High & 2 \\
\hline
\end{tabular}

From table 9 conclusion of factors affecting to select the maritime institutes that sort out according to significant factor as follow; student expectation $(\overline{\mathrm{x}}=3.94)$, tuition fee and scholarship $(\overline{\mathrm{x}}=3.77)$, admission system $(\overline{\mathrm{x}}=3.68)$, quality of education $(\overline{\mathrm{x}}=3.67)$, background $(\overline{\mathrm{x}}=3.56)$, back ground and private capacity $(\overline{\mathrm{x}}=3.54)$, generality of institutes $(\overline{\mathrm{x}}=3.53)$ and external influences $(\overline{\mathrm{x}}=3.37)$.

Table 9 Conclusion of factors affecting to select the maritime institutes

\begin{tabular}{lcclc}
\hline \multicolumn{1}{c}{ Factor } & $\overline{\mathrm{x}}$ & S.D. & Level & Sequence \\
\hline Student expectation & 3.94 & 0.82 & High & 1 \\
$\begin{array}{l}\text { Tuition fee and } \\
\text { scholarship }\end{array}$ & 3.77 & 0.89 & High & 2 \\
Admission system & 3.68 & 0.85 & High & 3 \\
Quality of education & 3.67 & 0.86 & High & 4 \\
$\begin{array}{l}\text { Background and } \\
\text { Private capacity }\end{array}$ & 3.54 & 0.94 & High & 5 \\
$\begin{array}{l}\text { Generality of } \\
\text { institutes }\end{array}$ & 3.53 & 0.99 & High & 6 \\
External influences & 3.37 & 0.94 & Medium & 7 \\
\hline Total & 3.64 & 0.90 & High & \\
\hline
\end{tabular}

\subsection{Comparison of factors affecting to select the maritime institutes}

According to the One Way ANOVA test, $\mathrm{F}=8.890$ and $\mathrm{P}-$ value $=0.000$ it mean that Thai merchant marine students from different institutes have different comment on selecting of marine institutes and the difference is statistically significant therefore the Scheffe's test method is selected for testing. 
Table 10 Classified by institutes

\begin{tabular}{|c|c|c|c|c|}
\hline Institutes & Amount & $\overline{\mathrm{x}}$ & & S.D. \\
\hline MMTC & 143 & 3.48 & & 0.45 \\
\hline $\mathrm{LF}$ & 59 & 3.63 & & 0.43 \\
\hline IMC & 184 & 3.69 & & 0.45 \\
\hline Total & 386 & 3.60 & & 0.46 \\
\hline Sources of variance & SS & MS & $\mathrm{F}$ & Sig \\
\hline Between Groups & 3.543 & 1.772 & 8.890 & 0.000 \\
\hline Withtin Groups & $76.329 \quad 383$ & 0.199 & & \\
\hline Total & $79.872 \quad 385$ & & & \\
\hline
\end{tabular}

From table 11 it showed that Thai merchant marine students from MMTC have comment on selecting of marine institutes different from Thai merchant marine student from IMC.

Table 11 Scheffe's test of maritime institutes selecting

\begin{tabular}{lccc}
$\begin{array}{l}\text { Factors Affecting to Select } \\
\text { the Maritime Institutes }\end{array}$ & MMTC & LF & IMC \\
\hline MMTC & & 0.109 & $0.000^{*}$ \\
LF & 0.109 & & 0.644 \\
IMC & $0.000^{*}$ & 0.644 & \\
\hline
\end{tabular}

According to the One Way ANOVA test, $F=1.499$ and $\mathrm{P}-$ value $=0.202$ it mean that Thai merchant marine students from different annual layer don't have difference in maritime institutes selecting.

Table 12 Classified by academic year

\begin{tabular}{lccc}
\hline \multicolumn{1}{c}{ academic year } & Amount & $\overline{\mathrm{x}}$ & S.D. \\
\hline $1^{\text {st }}$ year & 139 & 3.55 & 0.52 \\
$2^{\text {nd }}$ year & 120 & 3.65 & 0.39 \\
$3^{\text {rd }}$ year & 95 & 3.63 & 0.42 \\
$4^{\text {th }}$ year & 27 & 3.61 & 0.45 \\
$5^{\text {th }}$ year & 1 & 2.90 & 0.52 \\
& 382 & 3.60 & 0.46 \\
\hline
\end{tabular}

\begin{tabular}{lccccc}
\hline Sources of variance & SS & df & MS & F & Sig \\
\hline Between Groups & 1.241 & 4 & 0.310 & 1.499 & 0.202 \\
Withtin Groups & 78.029 & 377 & 0.207 & & \\
\hline Total & 79.270 & 381 & & & \\
\hline
\end{tabular}

According to the One Way ANOVA test, $\mathrm{F}=0.882$ and $\mathrm{P}-$ value $=0.475$ it mean that Thai merchant marine students from different grade level don't have difference in maritime institutes selecting.
Table 13 Classified by grade level

\begin{tabular}{|c|c|c|c|c|}
\hline Grade Level & Amount & $\overline{\mathrm{x}}$ & & S.D. \\
\hline Less than 2.01 & 24 & 3.57 & & 0.44 \\
\hline $2.01-2.50$ & 109 & 3.58 & & 0.46 \\
\hline $2.51-3.00$ & 171 & 3.65 & & 0.45 \\
\hline $3.01-3.50$ & 59 & 3.55 & & 0.48 \\
\hline \multirow[t]{2}{*}{ More then 3.50} & 19 & 3.54 & & 0.40 \\
\hline & 382 & 3.60 & & 0.46 \\
\hline Sources of variance & SS & MS & $\mathrm{F}$ & Sig \\
\hline Between Groups & 0.735 & 0.184 & 0.882 & 0.475 \\
\hline Withtin Groups & $78.535 \quad 377$ & 0.208 & & \\
\hline Total & $79.270 \quad 381$ & & & \\
\hline
\end{tabular}

According to the One Way ANOVA test, $\mathrm{F}=0.955$ and $\mathrm{P}-$ value $=0.446$ it mean that Thai merchant marine students from different domicile don't have difference in maritime institutes selecting.

Table 14 Classified by domicile

\begin{tabular}{|c|c|c|c|c|c|}
\hline Domicile & \multicolumn{2}{|c|}{ Amount } & \multicolumn{2}{|l|}{$\overline{\mathrm{x}}$} & S.D. \\
\hline $\begin{array}{l}\text { Bangkok and } \\
\text { Boundary }\end{array}$ & \multicolumn{2}{|c|}{70} & \multicolumn{2}{|l|}{3.66} & 0.48 \\
\hline North region & \multicolumn{2}{|c|}{59} & \multicolumn{2}{|l|}{3.66} & 0.47 \\
\hline Northeast region & \multicolumn{2}{|c|}{48} & \multicolumn{2}{|l|}{3.52} & 0.43 \\
\hline East region & \multicolumn{2}{|c|}{109} & \multicolumn{2}{|l|}{3.57} & 0.43 \\
\hline $\begin{array}{l}\text { Central region } \\
\text { West region }\end{array}$ & \multicolumn{2}{|c|}{59} & \multicolumn{2}{|l|}{3.63} & 0.36 \\
\hline \multirow[t]{2}{*}{ Southern region } & \multicolumn{2}{|c|}{37} & \multicolumn{2}{|l|}{3.55} & 0.60 \\
\hline & \multicolumn{2}{|c|}{382} & \multicolumn{2}{|l|}{3.60} & 0.46 \\
\hline Sources of variance & SS & $\mathrm{df}$ & MS & $\mathrm{F}$ & Sig \\
\hline Between Groups & 0.994 & 5 & 0.199 & 0.955 & 0.446 \\
\hline Withtin Groups & 78.276 & 376 & 0.208 & & \\
\hline Total & 79.270 & 381 & & & \\
\hline
\end{tabular}

According to the One Way ANOVA test, $\mathrm{F}=0.824$ and $\mathrm{P}-$ value $=0.510$ it mean that Thai merchant marine students from different Parent's income per month don't have difference in maritime institutes selecting. 
Table 15 Classified by parent's income per month

\begin{tabular}{|c|c|c|c|}
\hline $\begin{array}{l}\text { parent's income per } \\
\text { month (Baht) }\end{array}$ & Amount & $\overline{\mathrm{x}}$ & S.D. \\
\hline Less than 10,000 & 34 & 3.64 & 0.47 \\
\hline $10,001-20,000$ & 117 & 3.59 & 0.47 \\
\hline $20,001-30,000$ & 98 & 3.63 & 0.40 \\
\hline $30,001-40,000$ & 65 & 3.65 & 0.43 \\
\hline \multirow[t]{2}{*}{ More than 40,000} & 67 & 3.53 & 0.52 \\
\hline & 381 & 3.60 & 0.46 \\
\hline
\end{tabular}

\begin{tabular}{lccccc}
\hline Sources of variance & SS & df & MS & F & Sig \\
\hline Between Groups & 0.686 & 4 & 0.172 & 0.824 & 0.510 \\
Withtin Groups & 78.259 & 376 & 0.208 & & \\
\hline Total & 78.946 & 380 & & & \\
\hline
\end{tabular}

\section{DISCUSSION}

This research is an insight into Thai maritime students who are presently studying and their opinions on how they made a decision in selecting an institution for mariner officer profession based on different of institutes, academic years, cumulative score level, domicile and parent's monthly income. The results from study indicated seven factors that influenced the decision to choose an institution which every maritime institute in Thailand should use as guidelines for planning strategies for the development of the institution to become the institute that all students would want to attend. Moreover, there should be pro-activeness in public relations and suggestion of useful information including the promotion of cognition in mariner profession for attracting high-potential young people who live in various regions of the country to become mariner officers. And there should be continuous study about these factors affecting the decision of Thai maritime students to study in a Nautical Science Program according to a changing world to obtain accurate information, update and benefit for organization development.

\section{CONCLUSIONS}

The determinants that affect a Thai merchant marine student's decision in selecting a maritime institutes were permuted from high to low of factors respectively. Firstly, student expectations that concentrates on income after graduation. Secondly, tuition fees and scholarships that concentrates on institute tuition fees. Thirdly, the admission system that concentrate on the pattern for each institute Fourthly, the quality of education that concentrates on what the institute is known for. Fifth, background and private capacity that concentrates on monthly family income and physical ability. Sixth, generality of institutes that concentrate on education aid and lastly, external influences that depending on senior or alumni of high school.

The decision of the institution when classifying by academy found that the maritime students from different institutes have different opinion on the decision to select that institution. The students in different academic year, cumulative score level, domicile, and parent's monthly income have similar opinion on the decision to the institution.

\section{Acknowledgements}

I would like to thank Faculty of Logistics, Burapha University for this research found.

\section{References}

[1] Boonchaiyah, A. (2008), Motivation Factor for Furthering Master Degree in Recreation at Srinakharinwirot University, thesis (M.Sc.), Srinakarinwirot University.

[2] Chapman, D. (1981), A Model of Student College Choice The Journal of Higher Education 64(5), pp. 492-500.

[3] Creswell, J.W. (2003), Research Design: Qualitative, Quantitative, and Mixed Method, London: Sage Publications.

[4] George, D., \& Mallery, P. (2003), SSPS for Windows Step by Step version 11.0 (4th ed.), Pearson Education, Inc.

[5] Glasser, W. (1999), Choice Theory: A New Psychology of Personal Freedom, Harper Perennial Publisher

[6] Haruehansawasin and Kiattikomol, (2008), Factors Affecting High School Graduates' Decisions to Further Study in High Vocational Certificate Level in Business Computer Major, Private Vocational Schools in Bangkok, thesis (M.Sc.), King Mongkut's University of Technology Thunburi.

[7] Kulprapa, J. (2009), Motivation Factor for Selecting the 
Determinants Affecting Thai Merchant Marine Students' Decision in Selecting a Maritime Institute in Thailand: Nautical Science Program

University in Sripathum University, thesis (M.Ed.), Sripathum University.

[8] Lunsucheep, S. (2002), Motivation to Study at Mahidol University International College, thesis (M.A.), Mahidol University.

[9] Ohiwerei, F. O., \& Nwosu, B. O. (2009), Vocational Choices among Secondary School Students: Issues and Strategies in Nigeria, Asian Journal of Business Management, Vol. 1, pp. 1-5.

[10] Saithanu, K. and Mekparyup, J. (2011), Modeling to Predict Decision in Continuing Study for Master's Degree, Burapha Science Journal, Vol. 16, pp. 3-11.

[11] Ministry of Education. Web site. http://www.moe.go.th/English/ (access dated, 14.02.2011).

[12] Thai Instructor Senate. http://www.senate.go.th/th_senate/English/index.htm (access dated, 14.02.2011).

Received 10 April 2013

Revised 18 July 2013

Accepted 29 July 2013 